\title{
MDR1-Mediated Interaction of Digoxin with Antiarrhythmic or Antianginal Drugs
}

\author{
Mikio Kakumoto, ${ }^{a}$ Kohji Takara, ${ }^{b}$ Toshiyuki Sakaeda, ${ }^{*}, a$ Yusuke Tanigawara, ${ }^{c}$ Tomoko Kita, ${ }^{a}$ and \\ Katsuhiko OKUMURA $^{a}$ \\ ${ }^{a}$ Department of Hospital Pharmacy, School of Medicine, Kobe University; 7-5-2 Kusunoki-cho, Chuo-ku, Kobe 650-0017, \\ Japan: ${ }^{b}$ Department of Hospital Pharmacy, Faculty of Pharmaceutical Sciences, Kyoto Pharmaceutical University; 5 \\ Nakauchi-cho, Misasagi, Yamashina-ku, Kyoto 607-8414, Japan: and ${ }^{c}$ Department of Hospital Pharmacy, School of \\ Medicine, Keio University; 35 Shinano-machi, Shinjuku-ku, Tokyo 160-8582, Japan.
}

Received March 27, 2002; accepted September 9, 2002

\begin{abstract}
The multidrug transporter, MDR1-mediated interaction of digoxin with antiarrhythmic or antianginal drugs was examined in vitro by using the MDR1-overexpressing LLC-GA5-COL150 cells, which were established by transfection with human MDRI cDNA into porcine kidney epithelial LLC-PK 1 cells. Amiodarone, its active metabolite monodesethyl-amiodarone (DEA), and quinidine markedly inhibited the basal-to-apical transport (renal secretion) of $\left[{ }^{3} \mathrm{H}\right]$ digoxin and increased the apical-to-basal transport (reabsorption), but cibenzoline and lidocaine showed slight inhibition of the transport, and disopyramide and mexiletin had no such effects. The $\mathrm{IC}_{50}$ values for amiodarone, DEA and quinidine on $\left[{ }^{3} \mathrm{H}\right]$ digoxin transport in LLC-GA5-COL150 cells were 5.48 $\mu \mathrm{M}$, $1.27 \mu \mathrm{M}$ and $9.52 \mu \mathrm{M}$, respectively. These were comparable to, or only several times the achievable concentration in clinical use, suggesting that MDR1 could be responsible for the drug interaction between digoxin and amiodarone found in clinical reports and that DEA contributes the elevation of digoxin serum concentration. Similarly, dipyridamole altered the transport, but isosorbide showed only slight modification of the transport. The $\mathrm{IC}_{50}$ value for dipyridamole was $40.0 \mu \mathrm{M}$, also only several times the achievable concentration in clinical use, indicating a risk of interaction.
\end{abstract}

Key words MDR1; P-glycoprotein; digoxin; antiarrythmic drug; antianginal drug; drug interaction

Digoxin, a cardiac glycoside, is mainly prescribed for patients with congestive heart failure. Cardiac arrhythmia sometimes occurs in patients who are taking digoxin, ${ }^{1,2)}$ and thus antiarrhythmic drugs were often co-administrated with digoxin. In fact, antiarrhythmic or antianginal drugs were also prescribed for $25 \%$ and $21 \%$ of patients taking digoxin, respectively, in our hospital. ${ }^{3)}$ Digoxin is well known to have only a narrow therapeutic concentration range (trough: $0.5-$ $2.0 \mathrm{ng} / \mathrm{ml}$ ), and to be prone to drug-drug interaction. ${ }^{4)}$ Clinical reports suggested that the serum concentration of digoxin was elevated by amiodarone, ${ }^{5-7}$ quinidine, ${ }^{8-10}$ verapamil ${ }^{11,12)}$ and nicardipine, ${ }^{13)}$ and the daily dose of digoxin is adjusted based on a sophisticated serial monitoring of serum digoxin concentration.

Digoxin has been found to be mainly excreted by tubular secretion and glomerular filtration, ${ }^{4,14)}$ and tubular secretion has been demonstrated to be mediated via MDR1 by using LLC-GA5-COL150 cells, which were established by transfection of MDRI cDNA into porcine kidney epithelial LLC$\mathrm{PK}_{1}$ cells. $^{15,16)}$

Herein, the effects of amiodarone, its active metabolite monodesethyl-amiodarone (DEA) amd quinidine on the transport of $\left[{ }^{3} \mathrm{H}\right]$ digoxin was examined using LLC-GA5COL150 cells to elucidate whether MDR1 was responsible for the drug interaction between digoxin and amiodarone or quinidine found in clinical use. The possibility of interaction with other antiarrhythmic drugs, cibenzoline, lidocaine, disopyramide and mexiletin, and antianginal drugs, dipyridamole and isosorbide, was also examined. These are selected because they are more frequently used with digoxin compared with others, at least in our hospital.

\section{MATERIALS AND METHODS}

Chemicals Cibenzoline was a gift from Fujisawa Pharmaceutical Co., Ltd. (Osaka, Japan). DEA was a gift from Taisho Pharmaceutical Co., Ltd. (Tokyo, Japan). Amiodarone, mexiletin and quinidine were purchased from Sigma Chemical Co. (St. Louis, MO, U.S.A.). Disopyramide, lidocaine, dipyridamole and colchicine were purchased from Wako Pure Chemical Industries, Ltd. (Osaka, Japan). Isosorbide was purchased from Alexis Co. (San Diego, CA, U.S.A.). $\left[{ }^{3} \mathrm{H}\right]$ Digoxin $(595.7 \mathrm{GBq} / \mathrm{mmol})$ was purchased from Du Pont-New England Nuclear (Boston, MA, U.S.A.). Unlabeled digoxin was purchased from Aldrich Chemical Co. (Milwaukee, WI, U.S.A.). All other chemicals were of the highest purity available.

Culture of LLC-PK 1 and LLC-GA5-COL150 Cells LLC-GA5-COL150 cells were established by transfection of human MDRl cDNA into porcine kidney epithelial LLC-PK cells. ${ }^{15,16)}$ LLC-PK $_{1}$ and LLC-GA5-COL150 cells were maintained in the culture medium consisting of Medium199 (Dainippon Pharmaceutical Co. Ltd., Osaka, Japan) supplemented with $10 \%$ fetal bovine serum (FBS; BioWhittaker, Walkersville, MD, U.S.A.), with no antibiotics. Colchicine was also added to a final concentration of $150 \mathrm{ng} / \mathrm{ml}$ only for

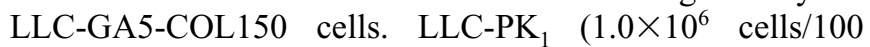
$\left.\mathrm{mm}^{2}\right)$ and LLC-GA5-COL150 cells $\left(1.5 \times 10^{6}\right.$ cells $\left./ 100 \mathrm{~mm}^{2}\right)$ were seeded on plastic culture dishes in $10 \mathrm{ml}$ of the culture medium. Monolayer cultures were grown in a humidified atmosphere of $5 \% \mathrm{CO}_{2}-95 \%$ air at $37^{\circ} \mathrm{C}$, and subcultured every 4 and $7 \mathrm{~d}$ for LLC-PK 1 and LLC-GA5-COL150 cells, respectively, with $0.02 \%$ EDTA- $-0.05 \%$ trypsin (Gibco BRL, Life Technologies, Inc., Grand Island, NY, U.S.A.).

Transcellular Transport of $\left[{ }^{3} \mathrm{H}\right]$ Digoxin across LLC- 
PK $_{1}$ and LLC-GA5-COL150 Cell Monolayers Transcellular transport of $\left[{ }^{3} \mathrm{H}\right]$ digoxin across LLC-PK $_{1}$ and LLCGA5-COL150 cell monolayers was examined as described previously. ${ }^{3,15,17-19)}$ Cells were seeded on Transwell ${ }^{\mathrm{TM}}$ (Cat. No. 3414, Costar, Cambridge, MA) at a density of $2.0 \times 10^{6}$ and $2.4 \times 10^{6}$ cells/well, respectively, and cultured under a humidified atmosphere of $5 \% \mathrm{CO}_{2}-95 \%$ air at $37^{\circ} \mathrm{C}$ for $3 \mathrm{~d}$ to form the monolayers. The MDR1 was highly expressed on the apical membrane in LLC-GA5-COL150 cell monolayers which accelerated the basal-to-apical transport (renal secretion) and inhibited the apical-to-basal transport (reabsorption). Basal-to-apical and apical-to-basal were examined independently. Three hours prior to the start of transport experiments, the culture medium was replaced with fresh culture medium. Colchicine was not included even for LLC-GA5COL150 cells. The transport study was initiated by replacement of the culture medium on the donor side (basal or apical side) with $2 \mathrm{ml}$ fresh culture medium containing $\left[{ }^{3} \mathrm{H}\right]$ digoxin $(100 \mathrm{~nm}, 18.5 \mathrm{kBq} / \mathrm{ml})$ together with [methoxy$\left.{ }^{14} \mathrm{C}\right]$ inulin $(6.0 \mu \mathrm{M}, 1.85 \mathrm{kBq} / \mathrm{ml})$, used as a cell monolayer integrity marker, and that on the receiver side (apical or basal, respectively) with $2 \mathrm{ml}$ fresh culture medium. The monolayers were incubated at $37^{\circ} \mathrm{C}$, and $25 \mu \mathrm{l}$ aliquots of the medium were sampled from the receiver side at three points $(1,2,3 \mathrm{~h})$. The data was accepted when the appearance of [methoxy- ${ }^{14} \mathrm{C}$ ] inulin on the receiver side was less than $0.4 \%$ per $h$ of the initial amount on the donor side.

The effects of antiarrhythmic and antianginal drugs on the transcellular transport of $\left[{ }^{3} \mathrm{H}\right]$ digoxin were evaluated by their addition to both sides of the monolayers at $1 \mathrm{~h}$ before the start of the transport experiments, and at the start of the transport experiments. The cells were exposed to them for $4 \mathrm{~h}$ total. The concentration of antiarrhythmic and antianginal drugs was $50 \mu \mathrm{M}$, which was used in the previous reports. ${ }^{3,17-19)}$ Although this is high, it is convenient to compare with the results on the previous reports. ${ }^{3,17-19)}$

The radioactivity associated with the collected media was counted in $3 \mathrm{ml}$ of ACS II (Amersham International) by liquid scintillation counting (LSC-5100, Aloka Co., Ltd., Tokyo). Data are presented as the percentage fraction of the initial amount of total radioactivity added to the donor side.

Data Analysis Statistical analysis of the data was performed by one-way analysis of variance followed by Scheffe's post-hoc test (two-tailed), with $p<0.05$ considered significant.

The $\mathrm{IC}_{50}$ values for amiodarone, DEA, quinidine and dipyridamole on $\left[{ }^{3} \mathrm{H}\right]$ digoxin transport were estimated as described previously. ${ }^{20,21)}$ The net basal-to-apical transport of $\left[{ }^{3} \mathrm{H}\right]$ digoxin at $3 \mathrm{~h}$ was calculated by subtracting the apicalto-basal transport from the basal-to-apical transport at $3 \mathrm{~h}$. At several concentrations, amiodarone, DEA, quinidine and dipyridamole caused inhibition of net basal-to-apical transport at $3 \mathrm{~h}$, shown as the percentage of reduction as compared with net basal-to-apical transport in the absence of drug. The percentage inhibition of net basal-to-apical transport at $3 \mathrm{~h}$ was plotted against the concentration of amiodarone, DEA, quinidine and dipyridamole, and fitted to the sigmoid $E_{\max }$ model by nonlinear least-squares fitting method (Solver, Microsoft ${ }^{\mathbb{B}}$ Excel 98).

$$
E=E_{\max } \times C^{\gamma} /\left(\mathrm{C}^{\gamma}+\mathrm{IC}_{50}{ }^{\gamma}\right)
$$

Where $E$ is the percentage inhibition (\%) by amiodarone, DEA and dipyridamole on net basal-to-apical transport of $\left[{ }^{3} \mathrm{H}\right]$ digoxin, $E_{\max }$ is the maximum inhibition rate (that is, $100 \%), C$ is the concentration of amiodarone, DEA, quinidine and dipyridamole $(\mu \mathrm{M})$ in the transport medium, $\mathrm{IC}_{50}$ is the concentration $(\mu \mathrm{M})$ producing $50 \%$ of $E_{\max }$, and $\gamma$ is the sigmoidicity factor.

\section{RESULTS}

Transcellular Transport of $\left[^{3} \mathrm{H}\right]$ Digoxin across LLC$P_{1}$ and LLC-GA5-COL150 Monolayers and Its Inhibition by Antiarrhythmic Drugs The basal-to-apical transport of $\left[{ }^{3} \mathrm{H}\right]$ digoxin was increased, and the apical-to-basal transport was decreased in LLC-GA5-COL150 cells when compared with parent LLC-PK 1 cells. The basal-to-apical transport of $\left[{ }^{3} \mathrm{H}\right]$ digoxin was higher than the apical-to-basal transport in LLC-GA5-COL150 cells, indicating that $\left[{ }^{3} \mathrm{H}\right]-$ digoxin was a substrate for MDR1 (Table 1).

Amiodarone and quinidine at $50 \mu \mathrm{m}$ extensively inhibited the basal-to-apical transport of $\left[{ }^{3} \mathrm{H}\right]$ digoxin, and increased the apical-to-basal transport in LLC-GA5-COL150 cells (Table 1, Figs. 1, 2), showing these drugs to be inhibitors of $\left[{ }^{3} \mathrm{H}\right]$ digoxin transport via MDR1, however disopyramide and mexiletin had no such effects even at $50 \mu \mathrm{M}$ (Table 1). Cibenzoline and lidocaine showed slight inhibition of the transport (Table 1). Similar to amiodarone, DEA $(10 \mu \mathrm{M})$ was demonstrated to be an inhibitor of MDR1-mediated transport of $\left[{ }^{3} \mathrm{H}\right]$ digoxin (Table 1). Inhibitory effects of amiodarone, DEA and quinidine on $\left[{ }^{3} \mathrm{H}\right]$ digoxin transport were concentrationdependent with an estimated $\mathrm{IC}_{50}$ of $5.48 \mu \mathrm{M}, 1.27 \mu \mathrm{M}$ and $9.52 \mu \mathrm{M}$, respectively (Figs. 1, 2, Table 2).

Transcellular Transport of $\left[{ }^{3} \mathrm{H}\right]$ Digoxin across LLCGA5-COL150 Monolayers and Its inhibition by Antianginal Drugs Dipyridamole also significantly suppressed the basal-to-apical transport, and increased the apical-to-basal transport in LLC-GA5-COL150 cells, and its effect was concentration-dependent with an estimated $\mathrm{IC}_{50}$ of $40.0 \mu \mathrm{M}$ (Ta-

Table 1. Effects of Antiarrhythmic and Antianginal Drugs $(10-50 \mu \mathrm{M})$ on Transcellular Transport of $\left[{ }^{3} \mathrm{H}\right]$ Digoxin (100 nM) in LLC-GA5-COL150 Cells

\begin{tabular}{|c|c|c|}
\hline \multirow{2}{*}{ Treatment } & \multicolumn{2}{|c|}{ Digoxin transport ( $\%$ of dose after $3 \mathrm{~h})$} \\
\hline & Basal-to-apical & Apical-to-basal \\
\hline LLC-PK 1 Cells & $10.4 \pm 1.0^{a)}$ & $4.40 \pm 0.33$ \\
\hline LLC-GA5-COL150 Cells & $21.9 \pm 0.2$ & $0.71 \pm 0.03$ \\
\hline \multicolumn{3}{|l|}{ Antiarrhythmic drugs } \\
\hline +Amiodarone & $6.66 \pm 0.12 *$ & $6.60 \pm 0.33 *$ \\
\hline$+\mathrm{DEA}$ & $7.80 \pm 0.24 *$ & $5.30 \pm 0.02 *$ \\
\hline +Cibenzoline & $19.3 \pm 0.7 *$ & $1.07 \pm 0.02$ \\
\hline +Disopyramide & $21.4 \pm 0.5$ & $1.77 \pm 0.28$ \\
\hline + Lidocaine & $16.9 \pm 0.2 *$ & $1.77 \pm 0.08$ \\
\hline +Mexiletin & $21.8 \pm 0.2$ & $1.85 \pm 0.29$ \\
\hline +Quinidine & $7.89 \pm 0.05 *$ & $6.31 \pm 0.20 *$ \\
\hline \multicolumn{3}{|l|}{ Antianginal drugs } \\
\hline +Dipyridamole & $11.1 \pm 0.2 *$ & $5.23 \pm 0.14^{*}$ \\
\hline + Isosorbide & $19.6 \pm 0.4^{*}$ & $1.94 \pm 0.08^{*}$ \\
\hline
\end{tabular}

DEA: monodesethyl-amiodarone, an active metabolite of amiodarone. a) Values are means \pm S.E.M. from three independent experiments, except for basal-to-apical and apical-to-basal transport across LLC-PK 1 cell monolayers $(n=9$ and 8 , respectively). Concentration of test drugs was $50 \mu \mathrm{M}$ except for DEA at $10 \mu \mathrm{M}$. $* p<0.05$ significantly different from the respective groups of LLC-GA5-COL-150 cells. 


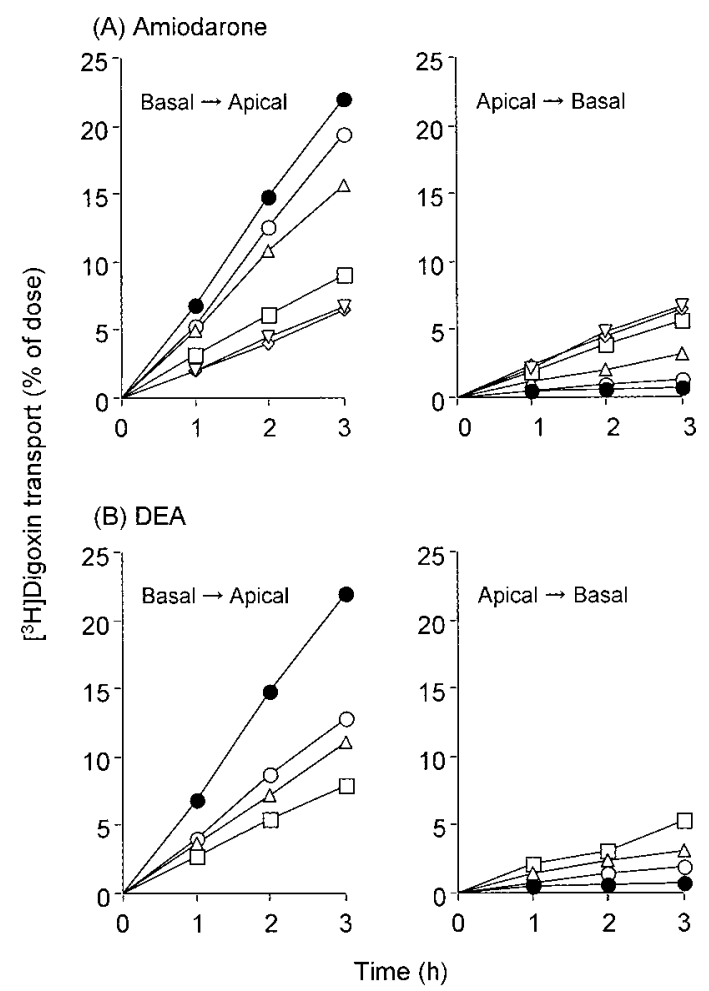

Fig. 1. Transcellular Transport of $\left[{ }^{3} \mathrm{H}\right]$ Digoxin across LLC-GA5-COL150 Cell Monolayers and Its Inhibition by Amiodarone (A) and DEA (B)

The concentrations of amiodarone and DEA were $0 \mu \mathrm{M}$ (control) $(\bullet), 1 \mu \mathrm{M}(\bigcirc), 5 \mu \mathrm{M}$ $(\triangle), 10 \mu \mathrm{M}(\square), 25 \mu \mathrm{M}(\diamond)$ and $50 \mu \mathrm{M}(\nabla)$. Each point represents the mean \pm S.E.M. of results from 3-6 independent experiments. In most cases, error bars were hidden in symbols.

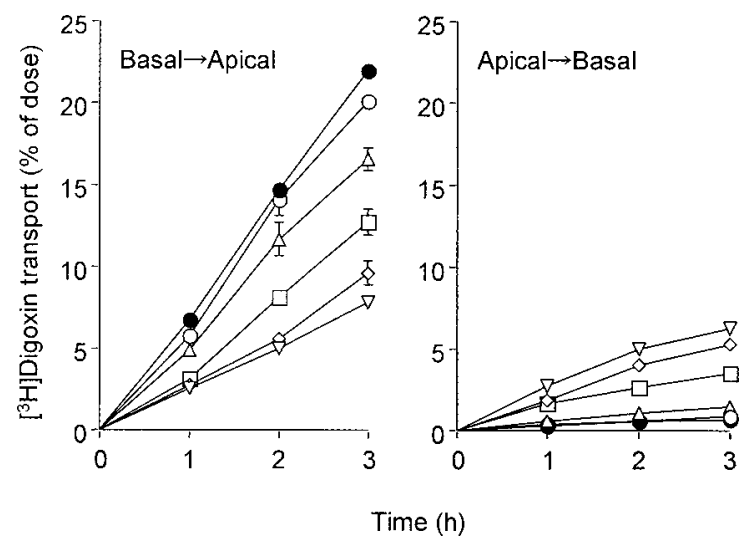

Fig. 2. Transcellular Transport of $\left[{ }^{3} \mathrm{H}\right]$ Digoxin across LLC-GA5-COL150 Cell Monolayers and Its Inhibition by Quinidine

The concentrations of quinidine were $0 \mu_{\mathrm{M}}\left(\right.$ control) $(\bullet), 1 \mu_{\mathrm{M}}(\bigcirc), 5 \mu_{\mathrm{M}}(\triangle), 10 \mu_{\mathrm{M}}$ $(\square), 25 \mu \mathrm{M}(\diamond)$ and $50 \mu \mathrm{M}(\nabla)$. Each point represents the mean \pm S.E.M. of results from three independent experiments. In most cases, error bars were hidden in symbols.

bles 1, 2, Fig. 3). In contrast, isosorbide showed only slight alteration of the transport (Table 1).

\section{DISCUSSION}

In previous study using this experimental system, the estimated $\mathrm{IC}_{50}$ values for nicardipine, verapamil, diltiazem and nifedipine on $\left[{ }^{3} \mathrm{H}\right]$ digoxin transport were obtained to be $4.54 \mu \mathrm{m}, 13.2 \mu \mathrm{m}, 77.7 \mu \mathrm{m}$ and $472 \mu \mathrm{m}$, respectively. ${ }^{19)}$ In clinical reports, nicardipine $(60-90 \mathrm{mg} / \mathrm{d})^{13)}$ and verapamil
Table 2. Estimated $\mathrm{IC}_{50}$ Values for Amiodarone, Monodesethyl-amiodarone, Quinidine and Dipyridamole on $\left.{ }^{3} \mathrm{H}\right]$ Digoxin Transport in LLCGA5-COL150 Cells

\begin{tabular}{lc}
\hline \hline Drugs & $\mathrm{IC}_{50}$ values $(\mu \mathrm{M})$ \\
\hline Amiodarone & $5.48^{a)}$ \\
DEA & 1.27 \\
Quinidine & 9.52 \\
Dipyridamole & 40.0
\end{tabular}

DEA: monodesethyl-amiodarone, an active metabolite of amiodarone. a) Each value represents the $\mathrm{IC}_{50}$ values for various drugs on the net basal-to-apical transport of $\left[{ }^{3} \mathrm{H}\right]$ digoxin at $3 \mathrm{~h}$.

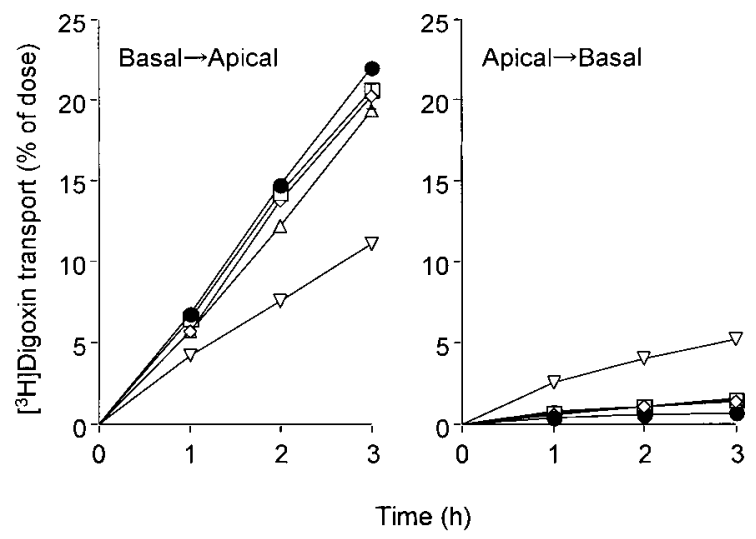

Fig. 3. Transcellular Transport of $\left[{ }^{3} \mathrm{H}\right]$ Digoxin across LLC-GA5-COL150 Cell Monolayers and Its Inhibition by Dipyridamole

The concentrations of dipyridamole were $0 \mu \mathrm{M}$ (control) $(\bullet), 5 \mu \mathrm{M}(\triangle), 10 \mu \mathrm{M}(\square)$, $25 \mu \mathrm{M}(\diamond)$ and $50 \mu_{\mathrm{M}}(\nabla)$. Each point represents the mean \pm S.E.M. of results from $3-$ 9 independent experiments. In most cases, error bars were hidden in symbols.

$(240 \mathrm{mg} / \mathrm{d})^{11,12)}$ are known to increase digoxin serum concentrations in human, but diltiazem $(90-180 \mathrm{mg} / \mathrm{d})^{22,23)}$ and nifedipine $\left.(55-60 \mathrm{mg} / \mathrm{d})^{24,25}\right)$ show no or only slight increase of serum concentrations. The total body clearance $(1 / \mathrm{h} / \mathrm{kg})$ of these calcium antagonists are about $0.50,0.80,0.70$ and 0.50 , respectively, and the absolute bioavailability are about $40 \%, 20 \%, 40 \%$ and $60 \%$, respectively, ${ }^{26,27)}$ therefore the steady-state concentrations are calculated around 0.07$0.15 \mu \mathrm{M}$. The estimated $\mathrm{IC}_{50}$ values are about $40-100$ times these concentrations for nicardipine and verapamil, and more than 500-3000 times for diltiazem and nifedipine. Relatively higher concentration of $\left[{ }^{3} \mathrm{H}\right]$ digoxin, $100 \mathrm{~nm}$ might be responsible for the discrepancies between the estimated $\mathrm{IC}_{50}$ values and steady-state concentrations, and relatively higher expression of MDR1 compared with human renal epithelial cells presumably contribute. It is impossible to estimate the possibility of drug interaction with digoxin by direct comparison of the estimated $\mathrm{IC}_{50}$ values and steady-state concentrations, however, the rank order of interaction might be estimated.

In this study, it has been indicated that amiodarone and DEA inhibited the transport of $\left[{ }^{3} \mathrm{H}\right]$ digoxin transport with estimated $\mathrm{IC}_{50}$ values of 5.48 and $1.27 \mu \mathrm{M}$, respectively (Table $2)$. These are comparable to the steady-state plasma concentrations of $1.06 \mu \mathrm{g} / \mathrm{ml}(1.55 \mu \mathrm{M})$ and $1.04 \mu \mathrm{g} / \mathrm{ml}(1.59 \mu \mathrm{M})$ at a dose of $200 \mathrm{mg} / \mathrm{d}$, respectively, ${ }^{28)}$ and MDR1 was suggested to be responsible for drug interaction with amiodarone, and that DEA contributed to the elevation of digoxin serum concentrations, although the comparison of concentrations of 
protein unbound form should be necessary. The half-lives of amiodarone and DEA after a single administration are 7.0 67.6 $\mathrm{h}$ and $40.1-113.4 \mathrm{~h}$, and are $14.9-30.2 \mathrm{~d}$ and $16.8-$ $39.3 \mathrm{~d}$ after repetitive administration, respectively. ${ }^{29)}$ These findings suggest that unexpected high serum concentrations of digoxin might occur several months following the discontinuation of amiodarone use. Quinidine also inhibited the transport of $\left[{ }^{3} \mathrm{H}\right]$ digoxin transport with the estimated $\mathrm{IC}_{50}$ value of $9.52 \mu \mathrm{M}$, being similar to the plasma concentration at a dose of $300 \mathrm{mg}$ three times a day, $3.9-8.0 \mu \mathrm{M}{ }^{30)}$ Thus, MDR1-based mechanism seems to be applied even for the interaction between digoxin and quinidine. Cibenzoline and lidocaine showed slight inhibition of the transport, and disopyramide and mexiletin had no such effects, suggesting their interaction with digoxin, if exists, is not due to MDR1.

Of the antianginal drugs, dipyridamole inhibited the transcellular transport of $\left[{ }^{3} \mathrm{H}\right]$ digoxin in LLC-GA5-COL150 cells with the $\mathrm{IC}_{50}$ of $40.0 \mu \mathrm{M}$ (Table 2). The maximum serum concentration of dipyridamole was around $2.0 \mu \mathrm{g} / \mathrm{ml}$ $(4.0 \mu \mathrm{M})$ following a single oral administration of $100 \mathrm{mg},{ }^{31)}$ and the initial whole blood concentration after intravenous administration of $20 \mathrm{mg}$ was around $8.0 \mu \mathrm{g} / \mathrm{ml}(16.0 \mu \mathrm{M}){ }^{32)}$ The estimated $\mathrm{IC}_{50}$ value is also only several times the achievable concentration in clinical use. Dipyridamole has been reported to increase the cytotoxicity of vinblastine and etoposide in drug-resistant tumor cells expressing MDR $1 .{ }^{33,34)}$ These findings indicate a risk of interactions.

In conclusion, it has been demonstrated that MDR1 is responsible for the drug interaction between digoxin and amiodarone or quinidine reported in clinical use, and that active metabolite, DEA also contributes the elevation of digoxin serum concentrations in the case of amiodarone.

Acknowledgments We sincerely thank Dr. Kazumitsu Ueda, Kyoto University Graduate, for technical assistance with the LLC-GA5-COL150 cell culture. The authors are grateful to Fujisawa Pharmaceutical Co., LTD. for cibenzolin, and Taisho Pharmaceutical Co., LTD. for monodesethyl-amiodarone.

\section{REFERENCES}

1) Shapiro W., Taubert K., Lancet, 2, 604-605 (1975).

2) Manninen V., Reissell P., Paukkala E., Clin. Pharmacol. Ther., 20, 266-268 (1976).

3) Takara K., Kakumoto M., Tanigawara Y., Funakoshi J., Sakaeda T., Okumura K., Life Sci., 70, 1491-1500 (2002).

4) Koren G., Clin. Pharmacokinet., 13, 334-343 (1987).

5) Moysey J. O., Jaggarao N. S., Grundy E. N., Chamberlain D. A., Br. Med. J., 282, 272 (1981).
6) Nademanee K., Kannan R., Hendrickson J., Ookhtens M., Kay I., Singh B. N., J. Am. Coll. Cardiol., 4, 111-116 (1984).

7) Fenster P. E., White N. W., Jr., Hanson C. D., J. Am. Coll. Cardiol., 5, 108 - 112 (1985).

8) Hager W. D., Fenster P., Mayersohn M., Perrier D., Graves P., Marcus F. I., Goldman S., N. Engl. J. Med., 300, 1238-1241 (1979).

9) Pedersen K. E., Hastrup J., Hvidt S., Acta Med. Scand., 207, 291-295 (1980).

10) Fenster P. E., Hager W. D., Goodman M. M., Clin. Pharmacol. Ther, 36, 70-73 (1984).

11) Belz G. G., Doering W., Munkes R., Matthews J., Clin. Pharmacol. Ther., 33, 410-417 (1983).

12) Rodin S. M., Johnson B. F., Wilson J., Ritchie P., Johnson J., Clin. Pharmacol. Ther., 43, 668-672 (1988).

13) Lessem J., Bellinetto A., Clin. Therpeutics, 5, 595-603 (1983).

14) Steiness E., Circulation, 50, 103-107 (1974).

15) Tanigawara Y., Okamura N., Hirai M., Yasuhara M., Ueda K., Kioka N., Komano T., Hori R., J. Pharmacol. Exp. Ther, 263, 840-845 (1992).

16) Ueda K., Okamura N., Hirai M., Tanigawara Y., Saeki T., Kioka N., Komano T., Hori R., J. Biol. Chem., 267, 24248-24252 (1992).

17) Takara K., Tanigawara Y., Komada F., Nishiguchi K., Sakaeda T., Okumura K., Biol. Pharm. Bull., 22, 1355-1359 (1999).

18) Takara K., Tanigawara Y., Komada F., Nishiguchi K., Sakaeda T., Okumura K., Pharm. Pharmacol. Commun., 6, 167-171 (2000).

19) Takara K., Sakaeda T., Tanigawara Y., Nishiguchi K., Ohomoto N., Horinouchi M., Komada F., Ohnishi N., Yokoyama T., Okumura K., Eur. J. Pharm. Sci., 16, 159-165 (2002).

20) Kusunoki N., Takara K., Tanigawara Y., Yamauchi A., Ueda K., Komada F., Ku Y., Kuroda Y., Saitoh Y., Okumura K., Jpn. J. Cancer Res., 89, 1220-1228 (1998).

21) Wandel C., Kim R. B., Kajiji S., Guengerich P., Wilkinson G. R., Wood A. J., Cancer Res., 59, 3944-3948 (1999).

22) Yoshida A., Fujita M., Kurosawa N., Nioka M., Shichinohe T., Arakawa M., Fukuda R., Owada E., Ito K., Clin. Pharmacol. Ther., 35, $681-685$ (1984).

23) Rameis H., Magometschnigg D., Ganzinger U., Clin. Pharmacol. Ther., 36, 183-189 (1984).

24) Schwartz J. B., Migliore P. J., Clin. Pharmacol. Ther, 36, 19-24 (1984).

25) Kirch W., Hutt H. J., Dylewicz P., Gräf K. J., Ohnhaus E. E., Clin. Pharmacol. Ther, 39, 35-39 (1986).

26) Abernethy D. R., Schwartz J. B., Clin. Pharmacokinet., 15, 1-14 (1988).

27) Echizen H., Eichelbaum M., Clin. Pharmacokinet., 11, 425-449 (1986).

28) Holt D. W., Tucker G. T., Jackson P. R., Storey G. C. A., Am. Heart J, 106, 840-847 (1983).

29) Poirier J. M., Escoubet B., Jaillon P., Coumel P., Richard M. O., Cheymol G., Eur. J. Drug Metab. Pharmacokinet., 13, 67-72 (1988).

30) Bolme P., Otto U., Eur. J. Clin. Pharmacol., 12, 73-76 (1977).

31) Nielsen-Kudsk F., Pedersen A. K., Acta Pharmacol. Toxicol., 44, 391-399 (1979).

32) Mahony C., Wolfram K. M., Cocchetto D. M., Bjornsson T. D., Clin. Pharmacol. Ther, 31, 330-338 (1982).

33) Shalinsky D. R., Andreeff M., Howell S. B., Cancer Res., 50, 75377543 (1990).

34) Turner R. N., Curtin N. J., Br. J. Cancer, 73, 856-860 (1996). 